University for Business and Technology in Kosovo

UBT Knowledge Center

UBT International Conference

2017 UBT International Conference

Oct 27th, 4:45 PM - 6:15 PM

\title{
Challenges of ICT Approval in Small And Medium Enterprises in the Republic of Albania
}

\author{
Lirinda Vako Abedini \\ International University of Struga, I.vako@eust.edu.mk \\ Rezarta Zhaku Hani \\ International University of Struga, r.hani@eust.edu.mk
}

Follow this and additional works at: https://knowledgecenter.ubt-uni.net/conference

Part of the Business Commons

\section{Recommended Citation}

Abedini, Lirinda Vako and Hani, Rezarta Zhaku, "Challenges of ICT Approval in Small And Medium Enterprises in the Republic of Albania" (2017). UBT International Conference. 239.

https://knowledgecenter.ubt-uni.net/conference/2017/all-events/239

This Event is brought to you for free and open access by the Publication and Journals at UBT Knowledge Center. It has been accepted for inclusion in UBT International Conference by an authorized administrator of UBT Knowledge Center. For more information, please contact knowledge.center@ubt-uni.net. 


\title{
Challenges of ICT Approval in Small And Medium Enterprises in the Republic of Albania
}

\author{
Lirinda Vako Abedini ${ }^{1}$, Rezarta Zhaku Hani ${ }^{2}$ \\ ${ }^{1}$ International University of Struga, Macedonia \\ 1.vako@eust.edu.mk \\ ${ }^{2}$ International University of Struga, Macedonia \\ r.hani@eust.edu.mk
}

\begin{abstract}
The process of globalization and digitalization have fundamentally changed the way of doing business and competition in the market. Information and Communication Technology is the cornerstone of this drastic change, bringing revolutionary changes to social and economic life. The purpose of ths paper is to analyze the benefits, challenges and strategies for minimizing the barriers of the adoption of information and communication technology, and to provide an overview of ICT in Albania by studying SME beliefs and attitudes regarding this issue. In addition to information on the current situation, the needs and difficulties of SMEs in identifying and using ICT will be identified and analyzed.

In this paper we will use quantitative research, online questionnaire for gathering data, and through comparative analysis we will draw a conclusion for ICT impact on the growth and competitiveness of SMEs.
\end{abstract}

Keywords: Information and Communication Technologies(ICT), business process, small and medium enterprises (SMEs)

\section{Introduction}

The recent increase in technological advancement has had strong impact on SMEs in other parts of the world including Albania.In this paper we show the impact and importance of information and communicationtechnologies (ICT) in small and medium-sized enterprises (SMEs) in developing countries as Albania. ICT is a broad term for a "wide range of software, hardware, telecommunications andinformation management techniques, applications, and devices that are used to create, produce, analyze, process, package, distribute, receive, store and transform information (Barba-Sanchez,2007)."

SMEs play a key role in the economy of developing countries and level of employment. In Albania, SMEs are often seen as the sources for a vital entrepreneurial economy,the majority of the workforce are employed by these SMEs. Research has shown that firms that have been able to effectively utilize Information and Communication Technology (ICT) can provide a strategic advantage which can positively influence their competiveness, increase knowledge, improved performance, improve relationships with customers and suppliers, increase efficiency etc...

A considerate number of SMEs in Albania, have effective computer systems to efficiently conduct business and have spent huge amounts of money on installing computer systems to support their business processes, while on the other hand some SMEs have limited financial and human resources to adopt ICT. 


\section{Objectives of the study}

The objective of this study is dual; firstly, it tries to investigate the impact of ICT on SMEs in the Republic of Albania, with particular attention to how ICT enhances competitiveness and business performance. Second, this research seeks to put SMEs in R. Albania in a wider context of world business in order to compare their innovation, competitiveness and performance contrast.

It is hoped that the results of this research will contribute to existing studies, particularly with regard to the ICT impact of small and medium enterprises in R Albania, as well as the obstacles and challenges faced during their transition to ICT adoption.

\section{Importance of SMEs}

There is no official definition of SMEs available, but According to European Commission, small to medium sized enterprises (SMEs) are those companies which have the number of employees up to 250 people and a maximum annual turnover of 50 million euro. Those companies, not only play an important role in the economy of a country, but are crucial to the country's economic stability. In Albania, SMEs make up more than $99 \%$ of all businesses and account for about 81.3\% of employment. (INSTAT, 2015) Moreover, SMEs are the true back-bone of the SouthEasternEuropean economy, being primarily responsible for wealth and economic growth, next to their key role in innovation. The above facts, show that SMEs play a very important role in the growth of economy of a country, hence those companies should be encouraged and supported consistently.

\section{Usage and impact of ICT by small and medium enterprises in Albania}

The evolution of technology influences significantly the small and medium businesses by changing the industry infrastructure and business operations and by creating the premises for the emergence of competitive advantages for those organizations that are adopting ICT in their business processes. The adoption of ICT by SMEs provides the ability of rapid access to data, assessment, processing and dissemination of large data volumes.Consequently, those SMEs which use ICT, have the opportunity to enter the international market and remain competitive despite the challenges of globalization, liberalization and scientific and technical progress.

Realizing the importance of SMEs for the economy of Albania and the impact of ICT on improving the performance of SMEs, we collect data about using questionnaire which consist from close-ended question with one alternative, more alternatives and mostly using Likert scale to where can choose their answer, and then we organize data in tables, charts and graphs.

As we can see from the table below, based on EU definition of SMEs, $94.8 \%$ of the respondents can be classified as Micro Enterprises (less than 10 employees), $4.2 \%$ as Small Enterprises (between ten and fifty) and 1\% Medium sized Enterprises (between fifty and two hundred fifty). 
Table 1: Types of SMEs based on number of Employees

\begin{tabular}{|l|l|l|}
\hline Types of SMEs & Percentage & $\%$. Of Employees \\
\hline Micro Enterprises (1-9 employees) & $94.8 \%$ & $41.6 \%$ \\
\hline Small Enterprises(10-49 employees) & $4.2 \%$ & $20.2 \%$ \\
\hline $\begin{array}{l}\text { Medium Sized Enterprises(50-249 } \\
\text { employees) }\end{array}$ & $1 \%$ & $19.5 \%$ \\
\hline
\end{tabular}

During our survey,based on collected data, we noticed that a large number of micro enterprises do not use any form of ICT. The reason seems to be the older generation of Owner/Manager who are not used to ICT and/or are low educated foreign labor force, lack of technological knowledge or low budget. Business productivity software, such as Microsoft Office packet (Microsoft Word, Excel, PowerPoint and Access) were used by $87 \%$ of the surveyed firms. About $62 \%$ of the firms use enterprise software such as E-Commerce, Inventory Management or ERP. Network solutions such as servers, routers and firewall were utilized in $45 \%$ of the SMEs. Data storage and security solutions were used by $21 \%$ of the surveyed firms, and wireless networking technologies and network security solutions by only $17 \%$ of the SMEs surveyed.

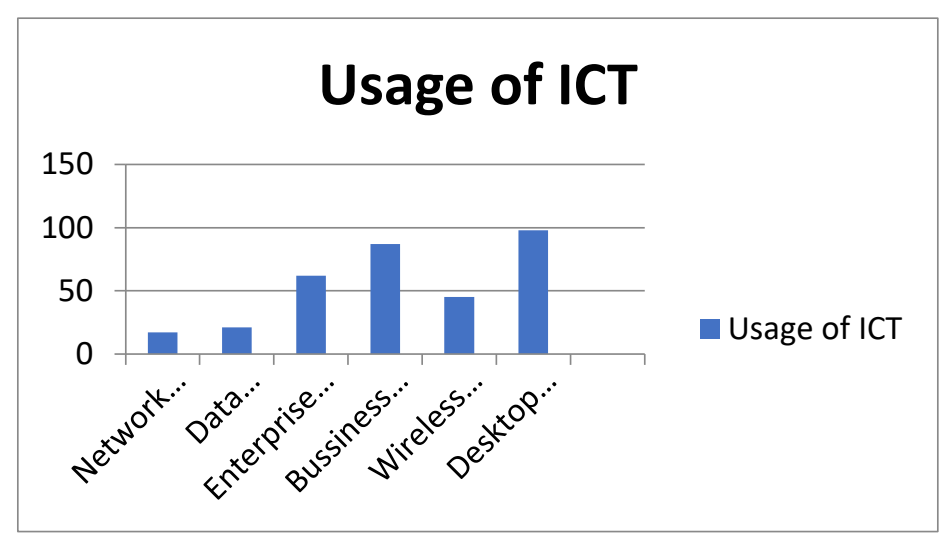

Figure 1: ICT infrastructure

Figure 2 shows that $75 \%$ of the SMEs assign less than $10 \%$ of their annual budget to ICT investment, $4 \%$ of the firms invest between $10 \%$ and $20 \%, 18 \%$ of the firms invest between $20 \%$ and $40 \%$ and only $6 \%$ of the surveyed firms assign greater than $40 \%$ of their budgets to ICT. 


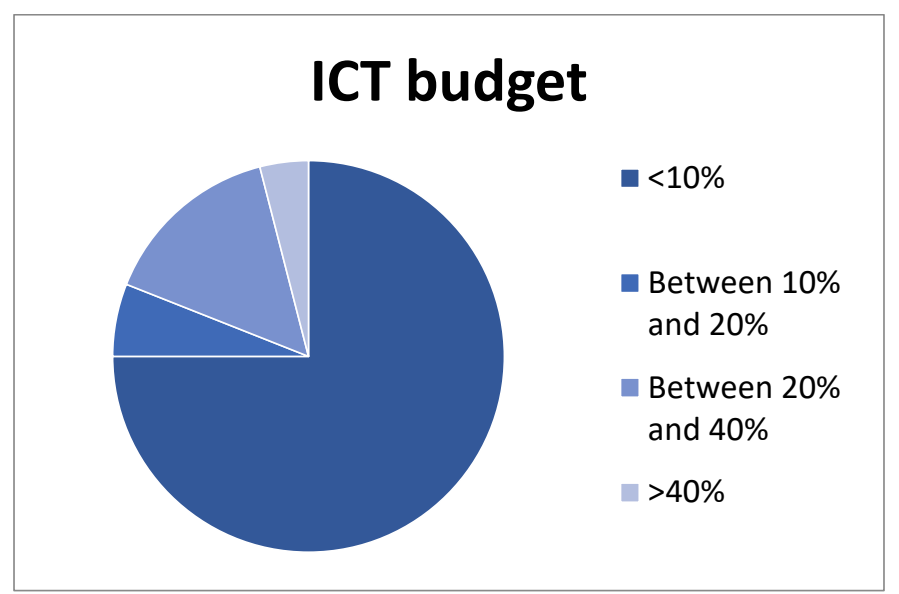

Figure 2: Proportion of budget assigned to ICT

\section{Barriers to ICT investment in SEE}

Although some of the SMEs in SEE are clearly aware of ICT benefits, there exist certain restrictions and barriers to ICT investment. We argue that this can be explained by the presence of barriers to ICT investment such as the low level of human capital and the lack of reorganization of the firm.

Based on investigations, $78 \%$ of the firms feel that a lack of necessary internal skills is a major barrier, because SMEs do not have enough human resources. $66 \%$ feel that the monetary costs of ICT solutions and implementation are too high. Almost $63 \%$ feel that there is not enough information available at their disposal about ICT. Of the respondents, about $49 \%$ of the firms are uncertain about retaining their ICT investment and $18 \%$ of the managers feel there is not enough support from the top-management in the firms. Figure 3 shows some of the main barriers to ICT adoption of SMEs in SEE.

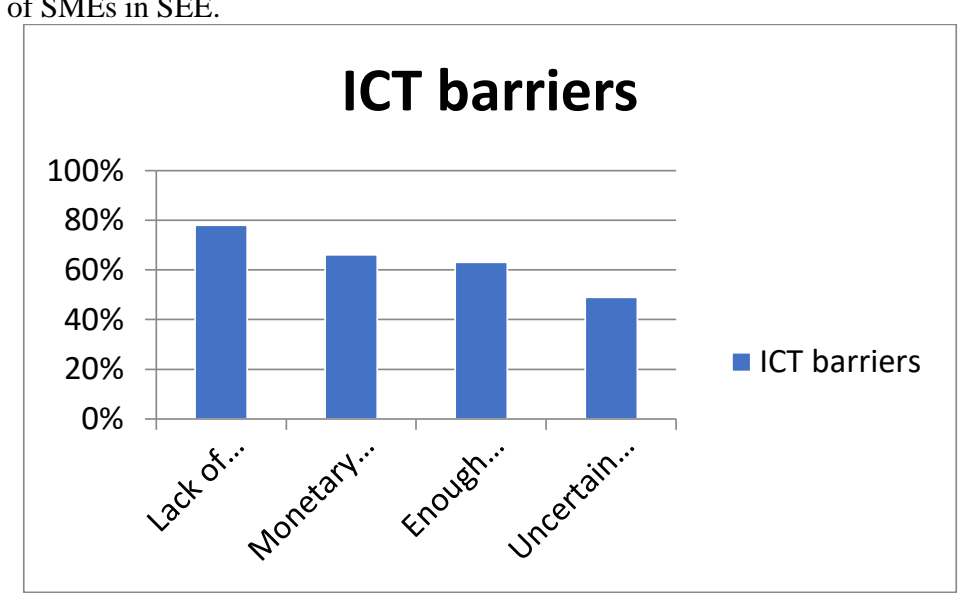

Figure 3: The main barriers to ICT adoption of SMEs in SEE. 


\section{Direct and indirect effects of ICT in small and medium enterprises}

ICT impacts on SME performance can be structured and analyzed through such indicators as efficiency, effectiveness and competitiveness, business innovations and intangible benefits. ICT is certainly a powerful influence on economic performance and can be characterized with a high degree of technological progress and productivity. ICT also has a significant social impact. There are two types of company performance:

- Financial performance

- Benefit

- Market value

- Growth

- Strategic performance

- Consumer satisfaction

- Employee satisfaction

- Environmental performance

- Social performance

\section{The role of government in ICT}

Respondents were asked to describe what kind of government support they need in terms of using ICT effectively. A total of $30 \%$ have argued that it is very useful for the government to invest more in ICT infrastructure. This is because ICT infrastructure has not yet reached the appropriate level. Most SMEs think that investment in ICT infrastructure will enable them to benefit from the various technologies available on the market. Moreover, a total of $71 \%$ have been expressed that it is very useful for the government to build the right legal framework to ensure security, confidence, privacy and consumer protection. In addition, almost $56 \%$ of respondents think that government should provide tax incentives and awareness on the benefits of using ICT (67\%), as well as provide training on advisory services $(71 \%)$. This indicates that there is a need for advice and relevant information from the government regarding the ICT benefits for SMEs.

\section{Conclusion}

In the presented paper we show the importance, impact and usage of ICT on SMEs in Albania. Conducted analysis and researches, indicate a strong positive correlation between ICT and economic efficiency and competitiveness of SMEs. This paper provides theoretical evidence of the direct and indirect effects of ICT on SME performance. From the study, we conclude that ICT can improve the overall performance, financial and operational performance of SMEs if used appropriately. The areas where ICT impact is greatest are: marketing, communication, networks and resources. ICT has an impact on improving external and internal communication plays a major role in the innovation performance of SMEs.

The ICT concept in general is still quite young in the Republic of Albania and as such continues to face a number of challenges, including poor telecommunications infrastructure, lack of qualified staff and trust, psychological barriers, digital divide and strategies and poor planning in ICT adoption etc. It seems that despite all these challenges, SMEs clearly understand the true potential of ICT. 
Regarding the government's role, the study has revealed that there is a need for the government to address more on the aspects of ICT infrastructure investment and be more aware of the benefits and adoption of ICT.

In conclusion, ICT is no longer a concept in the second plan, but a real reason and driving force that offers enterprises the roads to compete on a global scale efficiently and creates closer relationships between customers and suppliers. Adoption of ICT should often be seen as a normal way of doing business.

\section{References}

1. (Henry Ongori, Stephen O. Migiro, 2010)

2. (M. Kapurubandara, R. Lawson, 2006)

3. (Tam A.S.M, Chu L.K, SculliD, 2001)

4. (Parker, C.M., Castelman, T, 2007)

5. (P.Schubert, U.Leimstoll, 2007)

6. (P. Schubert, J.Fisher, U.Leimstoll, 2007)

7. (What is an SME? - European Commission, n.d.)

8. (D.Jamali, P.Lund-Thomsen, S.Jeppesen, 2015)

9. (SMEAL, 2017)

10. (INSTAT, 2015) 